\title{
MENINGKATKAN KEMAMPUAN HITUNG PERBANDINGAN MELALUI MEDIA FLOWCHART PADA SISWA KELAS V SDN KLUMPIT 03 KEC. SOKO-TUBAN
}

\author{
Sumijan ${ }^{1}$ \\ Kepala Sekolah Tuban Timur
}

\begin{abstract}
Mathematics is one of the basic sciences taught at all levels of schooling, with the aim to prepare students to be able to confront changing circumstances in life and in the world is always evolving, through acting on the basis of logical thinking, rational, critical, careful, honest, effectively and efficiently and can use matmatika and mindset of mathematics in daily life - today and in studying various sciences. This research uses classroom action research with the object of Action "Media Use Image" in the problem-solving arithmetic comparison in class V SDN Klumpit 03 Soko District of Tuban in academic year 2007/2008. research results or mendisplai describes the data, reflection data and research findings. Description of the results of the study include; First, the part that describes the process of implementation of research; The second part describes the results of a case study; Third, data analysis and discussion of case studies; Fourth, describe the results of model development; fifth, describes testing and validation of the model with experimental studies; sixth, test data analysis and statistical assumptions; The seventh, a general discussion; and eighth, summaries of research findings. Calculate the ratio of the expanded concept of fractional arithmetic concepts, hence the mastery of arithmetic concept will very much depend on the mastery of the main concept of fractions equivalent fractions; 2) Use of media images / charts can enhance the ability of arithmetic comparison in class V SDN Klumpit 03 Soko District of Tuban in academic year 2007/2008.
\end{abstract}

Keywords: math arithmetic capability, media flow chart

Abstrak: Matematika adalah salah satu ilmu dasar yang diajarkan pada semua jenjang sekolah, dengan tujuan untuk mempersiapkan siswa agar sanggup mengahadapi perubahan keadaan di dalam kehidupan dan di dunia yang selalu berkembang, melalui bertindak atas dasar pemikiran logis , rasional, kritis, cermat, jujur, efektif dan efisien serta dapat menggunakan matmatika dan pola pikir matematika dalam kehidupan sehari - hari dan dalam mempelajari berbagai ilmu. Penelitian ini menggunakan jenis Penelitian Tindakan Kelas dengan obyek Tindakan "Penggunaan Media Gambar" dalam penyelesaian soal hitung perbandingan pada siswa kelas V SDN Klumpit 03 Kecamatan Soko Kabupaten Tuban Tahun Pelajaran 2007/2008. hasil-hasil penelitian memaparkan atau mendisplai data, refleksi data dan temuan penelitian. Deskripsi hasil-hasil penelitian itu meliputi; pertama, bagian yang mendeskripsikan proses pelaksanaan penelitian; kedua, bagian yang mendeskripsikan hasil studi kasus; ketiga, analisis data dan pembahasan studi kasus; keempat, mendeskripsikan hasil penelitian pengembangan model; kelima, mendeskripsikan uji coba dan validasi model dengan penelitian eksperimental; keenam, analisis data dan uji asumsi statistik; ketujuh, pembahasan umum; dan kedelapan, ringkasan temuan penelitian. Hitung perbandingan merupakan konsep terkembang dari konsep hitung pecahan, karenanya penguasaan konsep hitung ini akan sangat bergantung pada penguasaan konsep pecahan utamanya pecahan senilai; 2) Penggunaan media gambar / bagan dapat meningkatkan kemampuan hitung perbandingan pada siswa kelas V SDN Klumpit 03 Kecamatan Soko Kabupaten Tuban Tahun Pelajaran 2007/2008.

Kata kunci: kemampuan hitung matematika, media flow chart

PENDAHULUAN

Matematika adalah salah satu ilmu dasar yang diajarkan pada semua jenjang sekolah, dengan tujuan untuk mempersiapkan siswa agar sanggup mengahadapi perubahan keadaan di dalam

\footnotetext{
${ }^{1}$ Kepala sekolah dan Pengawas Sekolah di Tuban Jawa Timur.
} 
kehidupan dan di dunia yang selalu berkembang, melalui bertindak atas dasar pemikiran logis , rasional, kritis, cermat, jujur, efektif dan efisien serta dapat menggunakan matmatika dan pola pikir matematika dalam kehidupan sehari - hari dan dalam mempelajari berbagai ilmu. (GBPP matematika 1994:1)

Sebagai ilmu dasar, maka matematika harus dikuasai dengan baik oleh peserta didik, karena rendahnya penguasaan anak terhadap ilmu dasar akan berdampak pada rendahnya pula penguasaan anak tersebut pada ilmu yang lain. Apabila berbagai cabang ilmu tidak dapat dikuasaai dengan baik oleh anak berarti pencapaian tujuan pendidikan nasional akan terhambat dan bahkan akan gagal pencapaiannya.

Kondisi itu tergambar pada beberapa dekade yang menunjukkan rendahnya penguasaan anak terhadap hasil belajar Matematika baik di tingkat nasional, regional, wilayah maupun sekolah.

Sebagai gambaran di SDN Klumpit 03 dalam 3 th terakhir diperoleh hasil EBTANAS / UJIAN KENDALI MUTU untuk mata pelajaran Matematika sebagai berikut:

Tabel 1. Hasil EBTANAS / UJIAN KENDALI MUTU untuk mata pelajaran Matematika SDN Klumpit 03 dalam 3 Tahun terakhir

\begin{tabular}{|c|c|c|c|}
\hline No & Tahun Pelajaran & $\begin{array}{c}\text { Rata }- \text { rata Nilai } \\
\text { Matematika }\end{array}$ & Keterangan \\
\hline 1 & $2000 / 2001$ & 3,87 & \\
2 & $2001 / 2002$ & 5,35 & \\
3 & $2002 / 2003$ & 5,60 & \\
\hline
\end{tabular}

Berbagai permasalahan yang sering timbul dalam pembelajaran matematika di SDN Klumpit 0302 antara lain : 1) Nilai hasil belajar Matematika yang selalu rendah; 2) Pembelajaran Matematika yang monoton serta lebih bersifat verbalisme; 3) Anak kurang gairah dalam mengikuti pembelajaran Matematika; 4) Anak kurang memiliki kemampuan untuk menyelesaikan soal hitung perbandingan; 5) Guru kurang dapat menggunakan metode pembelajaran secara bervariatif dan inovatif, sehingga pembelajaran cenderung monoton dan menjemukan; 6) Dengan media jari anak semakin senang dan mudah dalam menyelesaikan soal hitung perbandingan.

Atas dasar latar belakang di atas, maka judul yang kami angkat dari penelitian ini adalah "MENINGKATKAN KEMAMPUAN HITUNG PERBANDINGAN MELALUI MEDIA BAGAN / GAMBAR PADA SISWA KELAS V SDN KLUMPIT 03 KEC. SOKO TAHUN PELAJARAN
$2007 / 2008$ “

\section{TINJAUAN PUSTAKA}

Istilah Matematika berasal dari bahasa Yunani mathein atau mathemein yang artinya mempelajari, namun kata itu erat pula dengan kata sanskerta medha atau widya yang artinya kepandaian, ketahuan, atau intelegensi (Andi hakim Nasution, 1980. h 12)

Selanjutnya dalam Ruseffendi (1988, h. 2) diungkapkan beberapa pendapat tentang matematika, seperti menurut johnson dan Rissing (1972) menyatakan bahwa Matematika adalah pola berpikir, pola mengorganisasikan pembuktian yang logik ; matematika itu adalah bahasa, bahasa yang menggunakan istilah yang didefinisikan dengan cermat, jelas dan akurat representatifnya dengan simbol - simbol dan padat, lebih berupa simbul mengenai arti dari pada bunyi, matematika adalah pengetahuan struktur yang terorganisir.

Dari kondisi itu guru seyogyanya mengetahui kondisi seperti itu sehingga 
dapat menyiapkan kondisi siswanya agar mampu menguasai konsep - konsep yang akan dipelajari mulai dari yang sederhana sampai ke yang lebih kompleks.

Satu hal yang perlu diperhatikan oleh para guru sebelum membelajarkan matematika adalah harus mengenal konsep matematika yang hendak diajarkan itu, karena masing - masing konsep matematika menuntut strategi pembelajaran yang berbeda - beda. Konsep - konsep dalam matematika itu antara lain : 1) Konsep Dasar. Yaitu konsep yang umumnya bersifat baru sama sekali bagi siswa. Konsep yang merupakan bahasan pertama kalinya dipelajari oleh siswa. Oleh karena itu konsep dasar ini selanjutnya menjadi konsep prasyarat dalam memahami konsep berikutnya; 2) Konsep yang berkembang. Yaitu konsep yang berkembang dari konsep dasar dan merupakan terapan dari konsep dasar. Konsep berkembang ini merupakan kelanjutan dari konsep dasar, dan dalam mempelajarinya memerlukan konsep dasar. Dengan kata lain konsep jenis ini akan sangat mudah dipahami oleh siswa manakala siswa telah menguasai dengan baik konsep dasarnya; 3) Konsep yang harus dibina ketrampilannya. Konsep yang termasuk jenis ini dapat berupa konsep dasar dan dapat pula konsep berkembang. Konsep jenis ini perlu mendapat perhatian dan pembinaan dari guru sehingga para siswa mempunyai keterampilan dalam menggunakannya. Dengan adanya pembinaan ketrampilan terhadap konsep - konsep ini diharapkan proses pembelajaran matematika dapat mengkaji isu - isu tentang kurangnya ketrampilan berhitung. ( Depdikbud, 1998. 1.37)

Atas dasar uraian tersebut di atas maka mebelajarkan matematika tentu harus menyesuaikan dengan konsep yang akan diajarkan. Namun dalam membelajarkan konsep ada dua tahapan penting yaitu tahap persiapan dan tahap penyajian ( Warli dalam Majalah Quantum Tahun 2 Nomor 1 April 2008, h. 17 )

Dalam hubungannya dengan belaja konsep Gagne ( 1979 : 207 ) memaparkan kondisi belajar yang diharapkan terjadi adalah : 1) Penyajian contoh dan non contoh; 2) Penyajian obyek yang relevan dengan konsep yang dibahas; 3) Penyajian komponen konsep atau menyatakan konsep secara verbal; 4) Penampilan siswa dalam menyatakan konsep yang dibahas.

Sebagaimana diuraikan di atas bahwa konsep dalam belajar matematika dibedakan menjadi 3 yaitu konsep dasar, berkembang dan konsep yang perlu dibina ketrampilannya. Menghitung perbandingan di kelas 5 merupakan konsep lanjutan sekaligus dapat pula sebagai konsep yang perlu dibina ketrampilannya. Tanpa pembinaan yang rutin, intensip dan dengan strategi yang tepat, maka sulit bagi siswa untuk bisa menguasai dengan baik terhadap hitung perbandingan ini.

Terlebih untuk menyiapkan agar anak memiliki kemampuan matematika smart, maka terobosan - terobosan dalam pembelajaran matematika mutlak diperlukan. Untuk itulah maka guru senantiasa dituntut untuk selalu mengembangkan strategi pembelajaran sehingga siswa tidak merasa jemu dan semakin tertarik pada pelajaran Matematika.

Terkhusus untuk membelajarakan hitung Perbandingan, yang bagi siswa kelas $\mathrm{V}$ merupakan konsep terkembang dari hitung pecahan, maka sebelum siswa mengikuti pembelajaran pokok bahasan ini tentu ia harus sudah menguasai dengan baik tentang hitung pecahan, teramasuk di dalamnya pecahan senilai, menyederhanakan pecahan dsb.

Pada kenyataan siswa banyak mengalami kesulitan dalam penyelesaian soal hitung perbandingan, untuk itu maka penulis kembangkan pendekatan gambar / 
bagan untuk mempermudahnya. Pada menganut prinsip sebagai berikut: dasarnya pendekatan ini secara umum

1. Hitung perbandingan pada dasarnya memiliki prinsip yang sama dengan pecahan senilai. Contoh : Umur A : Umur B=3 : 4. Jika umur A 24 th, Berapakah Umur B ? Untuk menjawab soal di atas dapat diberikan bagan sebagai berikut :

\begin{tabular}{|l|l|l|l|l|l|l|l|}
\hline Umur A & 3 & & & & & & \\
\hline Umur B & 4 & & & & & & \\
\hline
\end{tabular}

Pada tahap awal siswa diajak melengkapi tabel di atas dimana umur A merupakan kelipatan 3 sedang umur B kelipatan 4, pada saat umur A mencapai 21 maka umur B = 28 . Perhatikan Tabel berikut :

\begin{tabular}{|l|c|c|c|c|c|c|c|}
\hline Umur A & 3 & 6 & 9 & 12 & 15 & 18 & 21 \\
\hline Umur B & 4 & 8 & 12 & 16 & 20 & 24 & 28 \\
\hline
\end{tabular}

Atau dengan tehnik yang lain yakni dengan memberikan ilustrasi kepada siswa, bahwa umur A mula - mula adalah 3 sekarang menjadi 21. Ini karena dikalikan dengan 7. karena umur A dikalikan dengan 7 maka umur B juga harus dikalikan dengan 7 sehingga hasilnya $=28$. Hal ini sama dengan pecahan senilai dimana $\frac{3}{4}=\frac{21}{\ldots \ldots \ldots .}$. Dalam hal ini kita harus kembali mengingat bahwa untuk mendapatkan pecahan senilai maka pembilang dan penyebut harus dikalikan atau dibagi dengn bilangan yang sama.Untuk jelasnya perhatikan bagan di bawah ini :

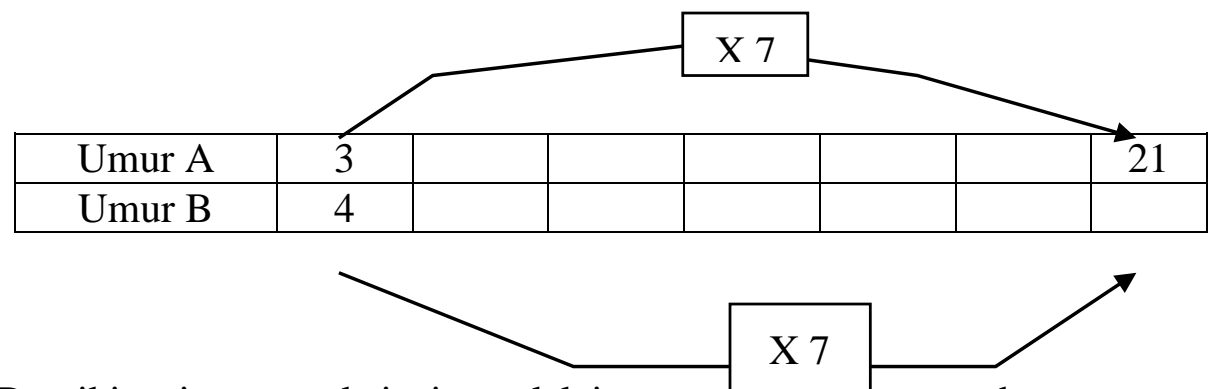

2. Demikian juga untuk jenis soal lain yang uा uaramnya ada unsur penjumlahan atau pengurangan, maka perbandingannya juga harus dijumlahkan atau dikurangi sesuai dengan karakter soal.

Contoh : Umur C : Umur D = 2 : 5. Jumlah Umur mereka 63 th. Berapa umur masing masing ?

Soal tersebut dapat diubah ke dalam bagan sebagai berikut :

\begin{tabular}{|c|c|l|l|l|l|l|l|l|l|}
\hline Umur A & 2 & & & & & & & & \\
\hline Umur B & 5 & & & & & & & & \\
\hline Jumlah & 7 & & & & & & & & 63 \\
\hline
\end{tabular}

Dengan tabel tersebut kita ajak anak untuk membahas bahwa jumlah perbandingan umur mereka pada awalnya adalah 7. Pada akhirnya menjadi 63.7 bisa menjadi 63 karena dikalikan dengan 9, maka semua perbandingan yang lain juga harus dikalikan dengan sembilan sehingga hasil selengkapnya menjadi sebagai berikut : 


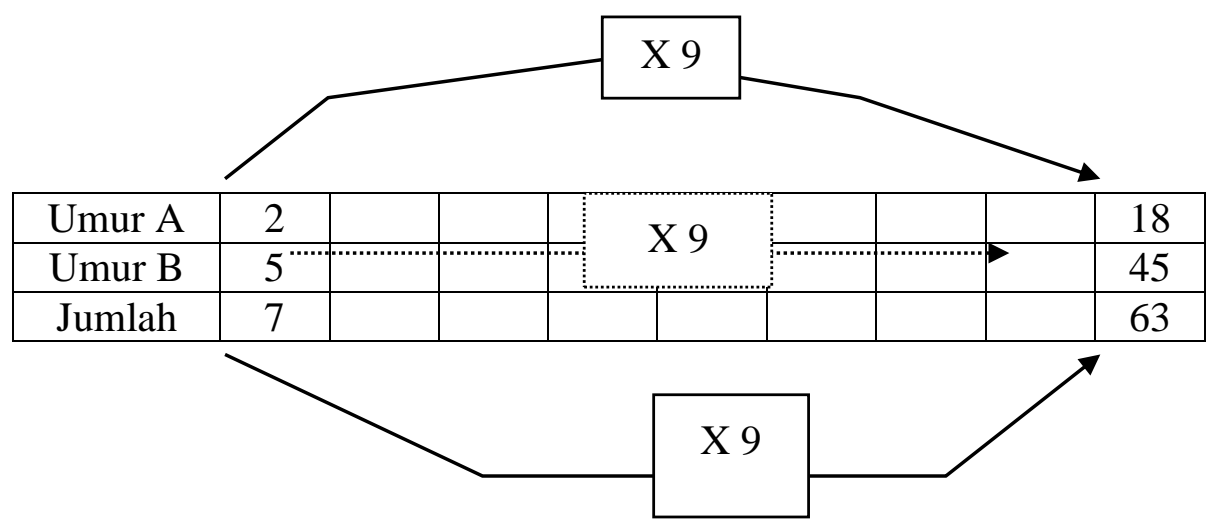

Dari diagram di atas maka dapat diketahui bahwa umur $A=18$ th dan Umur B $=45$ tahun.

Selanjutnya hasil tersebut kita coba untuk diterjemahkan ke dalam kalimat matematika, sebagai berikut :

Umur $A=18$ th dari mana bilangan 18 itu diperoleh ? ternyata dari $2 \times 9$. Dalam hal ini bilangan 9 adalah bilangan baru yang tidak ada dalam soal sehigga harus ditanyakan dari mana diperoleh angka 9 ? yakni dari $63: 7$ ( atau bisa ditulis $\frac{63}{7}$ )

Jadi Umur $A=\frac{63}{7} \times 2$ atau bisa ditulis $\frac{63 \times 2}{7}$ atau bisa juga ditulis $\frac{2}{7} \times 63=18$ th.

Demikian juga Umur B $=\frac{5}{7} \times 63=45$ th

\section{METODOLOGI PENELITIAN}

Penelitian ini menggunakan jenis Penelitian Tindakan Kelas dengan obyek Tindakan "Penggunaan Media Gambar" dalam penyelesaian soal hitung perbandingan pada siswa kelas V SDN Klumpit 03 Kecamatan Soko Kabupaten Tuban Tahun Pelajaran 2007/2008.

Penelitian ini dilakukan pada tanggal 8 April 2008 sampai dengan 18 April 2008 dengan mengambiil tempat di Kelas V SDN Klumpit 0302 Kecamatan Soko Kabupaten Tuban Tahun Pelajaran 2007/2008.

Yang menjadi populasi dalam penelitian ini adalah seluruh siswa kelas V SDN Klumpit 03 Kecamatan Soko Kabupaten Tuban Tahun Pelajaran 2007/2008. yang berjumlah 29 siswa.

Tehnik pengumpul data yang digunakan dalam penelitian ini adalah : 1) Teknik pengamatan digunakan untuk mengamati proses pencarian, kecepatan dan hasil kerja siswa dalam menyelesaikan hitung perbandingan; 2) Sedangkan untuk mengetahui seberapa jauh pengaruh peningkatan kemampuan hitung perbandingan siswa dengan media jari digunakan metode test.

Teknik analisa data digunakan untuk mengetahui tingkat keberhasilan penelitian tindakan ini maka data yang terkumpul selanjutnya diolah dan dianalisa dengan tehnik Analisis Deskriptif kualitatif dengan persente ( \% ). Dalam pada itu maka untuk menentukan ketuntasan belajar maka digunakan ketentuan $75 \%$ dari seluruh siswa telah menguasai materi dengan tingkat serapan $70 \%$.

Setelah data terkumpul dan dianalisa dengan tehnik Analisis Deskriptif kualitatif dengan persente maka hasilnya dijadikan dasar guna mengambil keputusan yakni seberapa jauh ada peningkatan kemampuan siswa dalam menyelesaikan soal hitung perbandingan setelah mendapat tindakan dengan Metode setengah beda. Kesimpulan dimaksud di 
dasarkan pada kecepatan dan ketepatan siswa dalam menyelesaikan soal hitung perbandingan dalam satuan waktu tertentu. Siswa baru dikatakan mencapai ketuntasan belajar dalam pokok bahasn hitung perbandingan bilangan dua angka jika ia menyelesikan soal dengan tepat dan dalam waktu yang cepat pula. Dalam hal ini siswa harus mengerjakan 10 butir soal hitung perbandingan bilangan dua angka dengan diberikan waktu paling lama 30 menit, berapapun soal yang dapat diselesaikan setelah waktua habis siswa harus menghentikan pekerjaannya . dari sinilah dapt diketahui hasil akhir baik secara klasikal maupun individual.

Dengan mengetahui prosentasi keberhasilan siswa secara individual maupun klasikal maka dapat diketahui tingkat efektifitas penggunaan metode ini. Dengan kata lain metode ini akan dianggap efektif apabila $75 \%$ siswa dapat mengalami kenaikan prestasi belajar dalam hal pengerjaan hitung perbandingan bilangan dua angka yang satuannya lima. Disamping itu juga dapat dilihat seberapa besar daya serap siswa secara klasikal mampu mengalami peningkatan prestasi setelah mengikuti pembelajaran dengan metode dimaksud.

\section{HASIL PENELITIAN}

Pada bab ini disajikan deskripsi pelaksanaan, hasil-hasil penelitian berikut pembahasannya, yang diarahkan pada jawaban masalah penelitian dan pencapaian tujuan penelitian. Deskripsi pelaksanaan penelitian menguraikan proses pelaksanaan penelitian secara konseptual. Sedangkan deskripsi hasilhasil penelitian memaparkan atau mendisplai data, refleksi data dan temuan penelitian. Deskripsi hasil-hasil penelitian itu meliputi; pertama, bagian yang mendeskripsikan proses pelaksanaan penelitian; kedua, bagian yang mendeskripsikan hasil studi kasus; ketiga, analisis data dan pembahasan studi kasus; keempat, mendeskripsikan hasil penelitian pengembangan model; kelima, mendeskripsikan uji coba dan validasi model dengan penelitian eksperimental; keenam, analisis data dan uji asumsi statistik; ketujuh, pembahasan umum; dan kedelapan, ringkasan temuan penelitian

Setidak-tidaknya ada dua hal pokok yang menjadi modal utama pengembangan pra model penelitian ini. Kedua hal pokok tersebut adalah: pertama hasil-hasil studi kasus. Kedua, hasil kajian pustaka serta hasil delphi dan uji lapangan secara terbatas. Dari kegiatan studi pendahuluan atau studi kasus telah dihasilkan (1) gambaran umum mengenai fenomena sosial di lokasi penelitian, (2) gambaran empiris dan aspirasi normatif pihak terkait seperti: peserta kursus, pengelola kursus, para pakar yang relevan, dan alumni kursus kewirausahaan.

Penelitian ini merupakan studi eksperimen, oleh karena itu mempersaratkan ditepatinya prosedur penelitian yang cermat, karena kelemahan dalam prosedur penelitian dapat menyebabkan invaliditas. Bila hal ini terjadi maka kemungkinan besar temuan penelitian juga tidak valid. Oleh karena itu diupayakan untuk melakukan kontrol ketat terhadap variabel-variabel eksperimen maupun variabel noneksperimen yang mungkin muncul dan mempengaruhi validitas penelitian.

\section{PEMBAHASAN}

Penelitian ini dilakukan pada siswa kelas V SDN Klumpit 03 Tahun Pelajaran 2007/2008 yang berjumlah 29 siswa dengan mengambil pokok bahasan "Pecahan dan Perbandingan", yang dilaksanakan mulai tanggal 8 April 2008 sampai dengan 15 April 2008 selama 3 kali pertemuan (6 Jam Pelajaran). Dari analisa data dengan menggunakan tekhnik presente dan mencari rata - rata, maka data yang dihasilkan adalah : 1) Pada akhir pembelajaran siklus 1 setelah diadakan evaluasi diperoleh rata - rata hasil 58,97, selanjutnya pada siklus 2 rata - rata hasil 
evaluasi diperoleh hasil 69,31 dan pada akhir siklus 3 hasil evaluasi diperoleh rata - rata 76,21. Dengan demikian maka nampak bahwa dengan penggunaan media gambar / bagan terbukti mampu meningkatkan kemampuan siswa dalam menyelesaikan soal hitung perbandingan;

2) Perolehan nilai maksimal pada akhir pembelajaran siklus 1 hanya meliputi sebagian kecil dari siswa saja yakni 13,79 $\%$, namun pada siklus 2 dan 3 berturut turut menjadi $28 \%$; 3) Ketuntasan belajar pada siklus 1 hanya dicapai oleh 11 anak ( $35 \%$ ) siswa yang dipandang telah tuntas dalam belajar, namun pada akhir siklus 2 dan 3 diketahui ada peningkatan prosentasi siswa yang mengalami ketuntasan belajar yakni sebesar $60 \%$ pada siklus 2 dan $73 \%$ pada siklus 3 .

Dari analisa data tersebut akhirnya dapat ditarik kesimpulan bahwa dengan penggunaan media gambar / bagan ternyata mampu meningkatkan kemampuan siswa kelas V SDN Klumpit 03 dalam menyelesaikan soal hitung perbandingan.

\section{KESIMPULAN DAN SARAN}

Setelah mengikuti paparan dari bab I sampai dengan Bab IV, maka dapat disimpulkan bahwa : 1) Hitung perbandingan merupakan konsep terkembang dari konsep hitung pecahan, karenanya penguasaan konsep hitung ini akan sangat bergantung pada penguasaan konsep pecahan utamanya pecahan senilai; 2) Penggunaan media gambar / bagan dapat meningkatkan kemampuan hitung perbandingan pada siswa kelas $\mathrm{V}$ SDN Klumpit 03 Kecamatan Soko
Kabupaten Tuban Tahun Pelajaran 2007/2008.

Saran yang disampaikan peneliti adalah : 1) Agar penguasaan hitung siswa meningkat maka penggunaan media gambar perlu ditingkatkan oleh para guru; 2) Agar konsep hitung perbandingan semakin mantap perlu dibiasakan dengan hitung mencongak pada saat awal pelajaran atau menjelang pulang sekolah (akhir pelajaran); 3) Agar murid tidak merasa takut terhadap pelajaran matematika maka guru diharapkan mampu membuat terobosan - terobosan yang dapat membantu siswa dalam belajar (matematika smart).

\section{DAFTAR PUSTAKA}

Depdikbud ( 1994 ), Garis-Garis Besar Program Pengajaran Matematika, Balai Pustaka Jakarta :

Depdikbud ( 1994 ), Matematika 3, Balai Pustaka Jakarta

Quantum ,Journal Pendidikan IKIP PGRI Tuban Tahun 2 No.1

Nasution Andi Hakim, ( 1987 ), Berbagai Pendekatan Dalam Prose Belajar Mengajar, Buna Aksara, jakarta.

Reseffendi E.T. ( 1991 ), Penilaian Pendidikan dan Hasil Belajar Siswa Khususnya Dalam Pengajaran Matematika, FKIP Bandung

Matematika. Jakarta : Delajar
Dikti PPLPTK
$\begin{aligned} & \text { Belajar Matematika, IKIP } \\ & \text { Malang }\end{aligned}$

